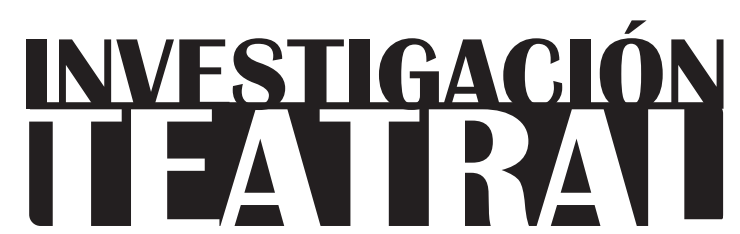

Revista de artes escénicas y performatividad

Vol. 10, Núm. 15

abril-septiembre 2019

Segunda época

ISSN impreso: 1665-8728

ISSN electrónico: 2594-0953

Universidad Veracruzana

\title{
Metateatralidad y recepción en el texto dramático del teatro español barroco
}

\author{
Ximena Gómez Goyzueta*
}

\footnotetext{
* Departamento de Letras del Centro de las Artes y la Cultura, Universidad Autónoma de Aguascalientes, México/Asociación Internacional de Teatro Español y Novohispano de los Siglos de Oro (aitenso).

e-mail:ximenaggoizueta@gmail.com
}

Recibido: 31 de octubre de 2018

Aceptado: 10 de enero de 2019 


\title{
Metateatralidad y recepción en el texto dramático del teatro español barroco
}

\section{Resumen}

Este trabajo propone una reflexión sobre la teatralidad y el metateatro desde el punto de vista de la recepción lectora del texto dramático. Se revisan postulados teórico-metodológicos sobre la teatralidad y el metateatro, así como su relación con el tópico del theatrum mundi, en el contexto del horizonte de expectativas del teatro español del siglo xviI. Con ello, se proponen algunas pautas metodológicas sobre el análisis de la recepción a partir de los efectos que pudo haber producido el uso del metateatro en estos corpora y que, en la actualidad, pueden afectar positivamente la captación de la atención del receptor/espectador.

Palabras clave: teatralidad, percepción, efectos, lectura, horizonte de expectativas, Theatrum Mundi.

\section{Metatheatricality and the Reception of the Dramatic Text in the Spanish Baroque Theater}

\begin{abstract}
This article purports to reflect on theatricality and metatheatre from the point of view of the reading reception of the dramatic text. Theoretical-methodological postulates about metatheatre and its relationship with the subject of Theatrum Mundi are reviewed in the context of the "horizon of expectations' of seventeenth-century Spanish theater. A number of methodological guidelines are proposed for the analysis of reception, considering the effects that metatheatre may have had on these corpora, which at the present time can positively contribute to catch the attention of the receiver/viewer.
\end{abstract}

Keywords: theatricality, perception, effects, reading, horizon of expectations, Theatrum Mundi. 


\section{Metateatralidad y recepción en el texto dramático del teatro español barroco ${ }^{1}$}

La cuestión no es saber de qué forma atraerlos [a la gente de teatro] hacia nuestras teorías, sino -modestia aparte-cómo influirán éstas en su práctica, del mismo modo en que su práctica ha motivado nuestras teorías.

Pavis, El análisis de los espectáculos

E presente ensayo se centra en el texto dramático para discurrir sobre la teatralidad y el metateatro con base en la relación que puede establecerse entre este último y el tópico del theatrum mundi. Hablaré de su recepción a partir de algunos mecanismos metateatrales que surgen en él y que pueden activar una percepción determinada de éste en una lectura analítica.

Para contextualizar la discusión teórica sobre el análisis del texto dramático, mi propuesta de lectura tomará en cuenta algunos postulados teórico-metodológicos del horizonte teatral, que permitirán generar una ruta metodológica con la que se puedan reflexionar y comprender algunos aspectos del fenómeno de la recepción en el teatro aurisecular y su actualización. Estos postulados parten, por un lado, de planteamientos semiológicos que se han hecho sobre el estudio de la teatralidad y su posible activación en la lectura del texto dramático desde su espectacularidad, los cuales han sido propuestos por María del

1 La investigación de este trabajo ha sido financiada por la SEP a través del programa PRODEP de Apoyo a la Incorporación de Nuevos Profesores de Tiempo Completo 2017-2018. 
Carmen Bobes Nabes en Semiología de la obra dramática, Óscar Cornago en su introducción a Estética de lo performativo de Erika Fischer-Lichte, y Carmen Leñero en La escritura invisible. Del faro al foro.

Parten también, por otro lado, de las consideraciones de Patrice Pavice sobre la necesidad de estudiar la composición artística y la puesta en escena de la dramaturgia, con base en el contexto histórico que le dan sus peculiaridades. Sin esta perspectiva, cualquier reflexión teórico-metodológica del texto dramático parecería sesgada. Además, estos postulados se relacionarán con algunas de las propuestas del "proceso de lectura" de Wolfgang Iser, con el objetivo de establecer las conexiones imprescindibles entre el horizonte de expectativas del repertorio del texto aurisecular y el horizonte de expectativas de una posible lectura crítica actualizada. Esto nos permitirá pensar de manera compleja el tema de la concreción de la obra, es decir, el lugar de encuentro (virtual) entre el texto y el lector desde la perspectiva que nos interesa en este artículo: la de la identificación de los posibles efectos que la metateatralidad puede producir en el lector, a partir de la cosmovisión del tópico del theatrum mundi barroco, pero que también se encuentra vigente en nuestro tiempo con las propuestas artísticas de las "nuevas teatralidades".

Para contextualizar el tema del metateatro en relación con el theatrum mundi, propongo una revisión a partir de los estudios pioneros de Lionel Abel en Metatheatre, que relacionan el tema con los tópicos de la vida como sueño y el mundo como teatro. Recurro también a una la lectura de El teatro y la teatralidad del barroco de Emilio Orozco (que aborda la misma cuestión en contexto del barroco español), así como a la recopilación de testimonios textuales de diversos ámbitos socio-culturales (el eclesiástico, el letrado, el de los propios poetas dramáticos) que hace José Hesse en Vida teatral en el Siglo de Oro, sobre la percepción de la teatralidad de la vida en la España aurisecular.

Asimismo, en la evolución del metateatro, retomo las propuestas más relevantes de Richard Hornby en Drama, Metadrama and Perception, que serán fundamentales para su comprensión no sólo especulativa, como en el caso de Abel, sino también de uso metodológico en el análisis. Igualmente, retomo el criterio sociocultural de Diez Borque en "Teatro español del siglo XVII", sobre la pluralidad de espacios de representación que son como un escenario, y la vida como un sueño.

Finalmente, para mi propuesta de análisis y crítica, me apoyo en las ideas de José Luis García Barrientos en Cómo se comenta una obra de teatro, quien retoma a Hornby desde la dramatología, sobre las distinciones entre el tratamiento especulativo del metateatro a partir de la cosmovisión del theatrum mundi y la identificación de técnicas metateatrales, así como de los niveles que puede desplegar el texto dramático desde el engaste metateatral.

Las siguientes reflexiones sirven como introducción a este panorama. El texto dramático es producto de la imaginación teatral, del modo particular en que el escritor concibe 
su obra. Carmen Leñero considera que "el espacio donde surge una pieza dramática es en principio un teatro interior - un ámbito virtual- en la conciencia del autor, quien, de entrada, imagina en términos espaciales, tridimensionales" (Del faro al foro 51-52). Así, la teatralidad emerge en el texto dramático que "fue motivado, destinado y modelado para su virtual realización escénica [...], ya sea que tal ulterior escenificación se lleve a efecto o no" (25).

De esta actividad creadora de la teatralidad se desprende, a su vez, "una manera específica de interpelar al prójimo, estableciendo un vínculo distintivo no sólo entre el autor y el lector (o espectador) sino también entre las voces que el autor vehicula y aquellas con las que el lector convive en su interior" (37).

Respecto al tema del receptor, Patrice Pavis hace una contraposición entre la concepción sociológica, empírica, del público, frente a la psicoanalítica o cognitiva del sujeto percibiente teórico (Diccionario de la performance 109), y argumenta que ésta debería ser superada. Pero el presente trabajo la tendrá en cuenta, como una distinción pensada a partir de momentos y recepciones diferentes del fenómeno teatral.

Propongo hacer un primer acercamiento a la recepción a partir de una lectura hermenéutica del texto dramático, que proporcione algunas claves para poder entender esta "manera específica de interpelar al prójimo" en relación con el metateatro. Para ello, reflexionaré sobre ciertos aspectos metodológicos que se involucran en esta lectura: la metateatralidad en la composición del texto dramático y sus probables efectos con base en la percepción que pueda tener un lector. Tras esta revisión, podrá establecerse un punto de partida más para un análisis del texto dramático, que tenga en cuenta la puesta en escena a partir de la metateatralidad.

\section{El teatro, el metateatro y la recepción}

Está visto que el metateatro y la autorreflexibilidad, son parte de la discusión teórica y de la práctica de "las nuevas teatralidades", están presentes desde el teatro clásico grecolatino y el teatro moderno occidental. Ello se debe, podemos decir, a que las implicaciones dramá-

2 Actualmente, menciona Ileana Diéguez, la teatralidad puede ser entendida "como instinto de transfiguración capaz de crear un ambiente diferente al cotidiano, de subvertir y transformar la vida, tal como lo planteó Nicolás Evreinov cuando estudiaba las disposiciones escénicas de la sociedad, interesado en observar 'el espectáculo sin fin' de la existencia humana y los roles sociales, más cercano a la premisa shakespeareana del mundo como un gran teatro y a buscar cada detalle que revelara 'la incesante teatralización de la vida" (párr. 17). Los artistas y los estudiosos de las "nuevas teatralidades" están considerando a partir de estas ideas, en términos generales, que la teatralidad del teatro se desprende de este "instinto de transfiguración" del ser humano, que es parte de su condición de homo ludens. 
ticas y escénicas de estos dispositivos, más allá de ser propias de convenciones históricas de la teatralidad, forman parte, en mayor o menor grado, de su lenguaje intrínseco. Así se manifiesta en obras que utilizan el metateatro temática y estructuralmente: el Anfitrión de Plauto, The Tempest de Shakespeare o Lo fingido verdadero de Lope de Vega, por mencionar algunos ejemplos (ver Abel, Metatheatre).

Es posible percibir en la lectura de estas obras cómo se pone de manifiesto el funcionamiento de sus propios mecanismos dramáticos, de manera que "hacen referencia a sí mismas". Esto puede presentarse en una puesta en escena o una performance, según Pavis, en tres formas generales: "puede tener que ver con la ficción de la obra (en cuyo caso se habla de metaficción), con su construcción (y deconstrucción) o con su temática (alusión, teatro dentro del teatro)" (Diccionario de la performance 48).

Ante este amplio panorama, la intención es buscar las formas en las que podemos percibir la metateatralidad en algunos textos dramáticos del Siglo de Oro español, los cuales ubicaremos según su momento histórico y las circunstancias de la representación, para así poder entender y concebir su recepción desde este punto de vista. En este sentido, Óscar Cornago piensa, a propósito del trabajo de Erika Fischer-Lichte, que:

hacer teoría como un modo de construir una forma de mirar, de tomar distancia para desarrollar una perspectiva de estudio (de representación), es un modo de estar en un presente, es una manera de ser histórico y dialogar con la historia desde un espacio y un lugar concretos, desde un aquí y un ahora, desde un cuerpo (Estética de lo performativo 14).

No propongo hacer una teoría sobre la metateatralidad, pero sí, tomando en cuenta esta reflexión, proponer algunos presupuestos sobre la lectura teatral que permitan entender los posibles efectos de la metateatralidad -dispositivo muy presente, por demás, en el teatro áureo-. ${ }^{3}$

Asimismo, es importante tener presente la siguiente afirmación de Erika Fischer-Lichte: "[...] las definiciones de teatro nunca se refieren a la esencia del teatro, más bien son consideradas como instrumentos en función de las distintas finalidades del análisis en el marco de una determinada teoría" (11). Para poder detectar la metateatralidad en la lectura del texto dramático, es necesario considerar ciertos puntos de partida teórico-metodológicos

3 Estos mecanismos que aparecen en el texto dramático pueden o no aparecer en la puesta en escena; además, como producto del trabajo de dramaturgia de la representación o como producto de la improvisación actoral, pueden aparecer otros mecanismos metateatrales que no están en el texto dramático. Es por ello que dejaremos para otra fase de esta investigación el cotejo y análisis de la puesta en escena. 
que ayuden a "adoptar una noción amplia de teatralidad -en tanto que modalidad de pensamiento y expresión que busca recuperar lo corpóreo, lo multidimensional y lo potencial-". Esta idea de Carmen Leñero "se desprende de una reflexión semiológica sobre lo teatral, cuyo objeto básico es 'el acto en situación', es decir, aquel cuya representación 'se da a ver"' (La escritura invisible 23).

Discurrir sobre una posible lectura del texto dramático que rastree su recepción con base en el metateatro significa, para esta investigación, tener presente la doble vida temporal de las obras: la de su momento histórico y la de su actualización en la lectura y en la representación. Pavis señala que "[...] la teoría del texto dramático deberá ser verificada por consideraciones históricas sobre la obra analizada" (“Tesis para el análisis" 9). Para cualquiera de los dos casos, teatralidad y metateatralidad en el texto dramático involucran al lector a través de un proceso de traducción del lenguaje de las palabras al de las acciones imaginadas. No obstante, es importante aclarar que, al hablar de la lectura del teatro español áureo en su momento, no hay que perder de vista la dificultad de poder rastrear esta actividad de recepción. Al respecto, Diez Borque deja muy claro lo siguiente:

si complejo es el problema del público en los distintos espacios de representación, en que hay posturas críticas encontradas, en las que no hace caso entrar aquí, no lo es menos, aunque sea incitación apasionante, el problema de la recepción del teatro impreso. A todos nos gustaría que hubiera respuestas satisfactorias a preguntas, entre otras, tan importantes como ¿quién leía el teatro?, ¿cuáles eran las relaciones entre lectura y representación?, ¿qué proporción ocupaban los libros de teatro en las bibliotecas?, ¿en qué medida condicionaban la clase social, el precio?, y tantas otras preguntas. Pero suele ocurrir que no haya respuestas a la altura del interés de las cuestiones (Literatura 80).

Por ello, en este trabajo reconstruiremos el horizonte de expectativas del texto dramático con base en el topos barroco del theatrum mundi en la sociedad de aquella época y su uso en el teatro, para desde allí proponer reflexiones metodológicas sobre una lectura metateatral de estas obras. Para esto último, asumimos una operación cognitiva de carácter científico e intelectivo, puesto que el lector, con su propio horizonte y el del texto, debe disponer su atención de manera especial ante un texto que fue imaginado por el dramaturgo para su representación. Así, la percepción de la teatralidad del texto puede activarse en un primer nivel más o menos inmediato, el del lenguaje propio del teatro. Las palabras encarnan

4 Si bien esta concepción de la teatralidad que propone Carmen Leñero está considerada en función de textos no dramáticos, es pertinente y útil para el interés de este trabajo, puesto que parte de reflexiones sobre "la imaginación teatral" y el "modo de lo teatral". 
en personajes que, por este "darse a ver", adquieren tridimensionalidad en la imaginación tanto del escritor como del receptor, es decir, movimiento, voz, tono, acción... De esta manera, entran en juego estas voces conducidas por el dramaturgo que, a su vez, adquirirán su propia dimensión en la imaginación del receptor.

La percepción de la metateatralidad se activaría en un segundo grado de reconocimiento, que, como dijimos al principio, dependerá de cada lectura particular, pero sin perder de vista la necesidad de establecer las coordenadas espacio-temporales que le dieron vida a ese texto. Esto es así porque, como señalan Nara Araújo y Teresa Delgado a propósito de la teoría de la recepción, "la forma de leer los textos literarios ocurre en un proceso ininterrumpido, y la lectura expresa, hasta cierto punto, la inagotabilidad de ellos, condición de la realización individual en aquélla" ("El proceso de lectura" 486).

Antes de seguir, es importante tener en cuenta las siguientes precisiones de Lilian von der Walde sobre la polisemia del texto a partir de la pluralidad de lecturas. Von der Walde dice que hay que:

subrayar la obligación del especialista de poner verdaderos límites a su "recepción"; esto es, apegarse a lo que realmente aparece en la composición de que se trate, mediante una lectura sumamente cuidadosa y el análisis, obviamente, de la recepción de la época en la que fue escrita y copiada. [Así pues], por ningún motivo el crítico, en virtud de su libertad receptiva, debe "completar" al autor, volverse una suerte de coautor (4).

Asimismo, los siguientes cuestionamientos de Pavis sobre el análisis del texto dramático son relevantes para una adecuada delimitación del proceso de recepción teatral:

¿Es [...] legítimo hablar del texto dramático en general? ¿No convendría mejor hablar de la dramaturgia, ese arte de la composición de obras que tiene igualmente en cuenta la práctica teatral? Habría, entonces, que situar esta dramaturgia en la historia, verificar si ella es clásica, romántica, realista, absurda, etc. Del mismo modo que resulta problemático hablar del teatro, en general, no sabríamos hacer la teoría del texto dramático en sí. Debemos considerarla en su marco histórico específico; por lo tanto, la teoría del texto dramático deberá ser siempre verificada por consideraciones históricas sobre la obra analizada ("Tesis para el análisis" 9).

Si, como Pavis, pensamos el texto dramático como dramaturgia -es decir, en su sentido artístico y partiendo de su historicidad-, podemos apoyarnos para nuestra propuesta en algunos de los postulados sobre la recepción en "El proceso de lectura" de Wolfgang Iser: 
La obra literaria posee dos polos que podemos llamar polo artístico y polo estético, siendo el artístico el texto creado por el autor, y el estético la concreción realizada por el lector. El lugar de la obra de arte es la convergencia de texto y lector, y posee forzosamente carácter virtual, puesto que no puede reducirse ni a la realidad del texto ni a las disposiciones que constituyen al lector (487).

Tenemos, así, dos elementos en el proceso de lectura: la dramaturgia o el texto dramático y el receptor. Éstos se reúnen en el acto de lectura, del cual se genera la realización de la obra de un modo virtual. El acto de lectura se constituye, dice Iser, bajo las "reglas de juego" de "un juego de fantasía" que tiene lugar en el texto a partir de "lo no dicho" por parte del autor, de los "vacíos en las revueltas del diálogo" (488-489).

Estos vacíos son, según García Barrientos, “característicos del género [teatral]”. El lector los llenará, dice el crítico, a través de una reconstrucción y "con ayuda de su imaginación, hasta cierto punto, de los cuatro elementos inherentes al teatro (texto y representación): unos personajes en un tiempo y un espacio que se muestran para un receptor (lector o público). Esto corresponde a lo que él llama "una lectura teatral de la obra dramática" (39), es decir, "reproducir mentalmente una representación de la misma" (40). La dramaturgia se constituye, entonces, dice Carmen Leñero, "en una especie de territorio ceremonial y opera como mediador entre la referencia abstracta y la experiencia sensible, participando así de la llamada 'magia teatral': encarnar lo ausente, darlo a ver y permitir que ello actúe en el espectador" (La escritura invisible 27).

Si bien Von der Walde señala que debemos ser cuidadosos para que ese "llenado" por parte del receptor no se convierta en un acto de libre interpretación y recreación del texto al servicio de la pura imaginación, para el caso del texto dramático dicha reproducción mental de la virtual puesta en escena responde esencialmente a la naturaleza del acto comunicativo propio del género. A propósito de ello, María del Carmen Bobes ha hablado del teatro como "fenómeno literario y como fenómeno espectacular, en su doble dimensión de texto escrito y texto representado" (14). Esta doble dimensión implica que

el texto dramático inicia un proceso de comunicación que no culmina en la lectura, ya que se prolonga hasta la representación, siempre colectiva. La representación no es algo añadido al texto y ajeno a él, ya que está virtualmente incluida como algo constitutivo del mismo texto. Esta circunstancia condiciona todo el modo de recepción, como es lógico, pero también condiciona fuertemente la creación y la forma del texto literario dramático, es decir, afecta a todo el proceso semiótico y a sus partes (17). 
Esto significa que, aunque no seamos actores y directores leyendo la dramaturgia para ponerla en escena, solemos leerla en una doble dimensión: la literaria y la espectacular, es decir, haciendo - como señala García Barrientos- una lectura teatral. De allí que el ejercicio lector de imaginar la virtual representación, siempre teniendo presente el horizonte de expectativas del texto, sea necesario para estudiar este género.

El horizonte de expectativas del texto tiene que ver, dice Iser, con que "todo texto literario incorpora, en mayor o menor medida y con más o menos intensidad, normas sociales, históricas y contemporáneas, y las correspondientes referencias a la tradición literaria. Forman lo que se llama el repertorio del texto" ("El proceso de lectura" 504). De manera que la "lectura teatral de la obra dramática” tiene que tomar en cuenta este repertorio, para poder evitar, así, el uso exclusivo de "las normas familiares". Por tanto, proponemos hacer una virtual representación del texto dramático que sea pertinente, en este caso, bajo un repertorio que hemos considerado desde el metateatro en la España áurea del siglo XVII.

\section{El metateatro}

Según ha identificado la crítica, el metateatro aparece en los textos dramáticos desde dos perspectivas. Por un lado, la ya clásica, planteada por Abel, que ve al metateatro como un "género" de obras en las que los personajes viven la "vida" como ya teatralizada (el mundo como teatro y el teatro como escenario del mundo). Ésta es de carácter especulativo, pues implica el modo en el que los personajes son construidos para reflexionar sobre su entorno y sobre sí mismos a partir de la metáfora del theatrum mundi.

Por otro lado, tenemos la perspectiva que se manifiesta, específicamente, a través de técnicas metateatrales por parte de los dramaturgos, y que pueden percibirse en la estructura del texto y en relación con los personajes y la acción. Estas técnicas son, en términos generales, el teatro dentro del teatro, la representación de más de un papel por un solo personaje y la autoconsciencia dramática (Hornby, Drama 82; Larson, "El metateatro" 1015).

Así también, José Luis García Barrientos establece, más o menos, la misma distinción entre el modo especulativo (el mundo como teatro y el teatro como escenario del mundo) y el modo de las técnicas dramáticas del metateatro. El modo dramático está constituido, propone él, de tres formas: el metateatro, el metadrama y la metadiégesis. El metateatro es "la forma genuina del teatro en el teatro que implica una puesta en escena teatral dentro de otra" (232). El metadrama es:

un concepto más amplio, que incluye el anterior, pero que rebasa todas aquellas manifestaciones en que el drama secundario, interno o de segundo grado se escenifica 
efectivamente, pero no se presenta como producido por una puesta en escena, sino por un sueño, un recuerdo, la acción verbal de un narrador (Ibídem).

Y la metadiégesis corresponde a "una fábula secundaria, argumento de segundo grado o historia dentro de otra historia" (Ibídem). Sobre el modo especulativo, García Barrientos señala que es:

el reflejo de estas categorías formales en el plano del contenido [...] De este mismo modo caen también, me parece, algunas de las que Hornby considera variedades de metadrama, como los personajes actuando dentro de personajes o las ceremonias dentro de la obra. [...] El carácter reflexivo o especular que les es común puede tematizarse sin afectar a la estructura dramática [...] o bien puede formalizarse en la estructura (niveles), con mayores o menores consecuencias (incluso ninguna) (234).

En la práctica teatral, la distinción entre estas dos visiones del metateatro puede no ser clara. En relación con esto, cito a Jesús G. Maestro:

al contrario de lo que sucede en la expresión metapictórica, como en las Meninas, por ejemplo, ante las que el espectador puede contemplar simultáneamente los diferentes planos reflejados por el pintor, el espectáculo metateatral no siempre permite observar con la misma facilidad o intensidad [que la metapintura] las dos escenas que se representan en simultaneidad de tiempo y en identidad o contigüidad de espacio (599).

Esta dificultad es igualmente problemática para la lectura del texto dramático. Puede ocurrir que cualquier aspecto del texto sea interpretado a través de estas modalidades sin que, efectivamente, exista allí metateatro. Por ejemplo, en su apartado dedicado a la "visión" o a aquello que "afecta a la recepción dramática" (Cómo se comenta 193), García Barrientos refiere también el ejemplo de las Meninas para hablar de los "niveles dramáticos" a propósito del "teatro en el teatro". García Barrientos identifica tres niveles: "extradramático, el cual equivale al plano escénico; intradramático, equivale al plano ficticio; y metadramático, equivale al drama dentro del drama" (231). Estas distinciones teóricas son claras, pero al momento de la lectura, la identificación del metateatro dependerá del texto en cuestión y de que el mecanismo metateatral se active en la percepción del lector.

Es necesario tener en cuenta, durante el proceso de lectura, unos instrumentos de análisis que nos permitan no ver metateatro en cualquier punto que nuestro deseo imaginativo nos haga reaccionar. "A esta propensión un tanto paranoica sólo cabe oponer el criterio de la sensatez o la pertinencia, más fácil de aplicar que de definir", observa García 
Barrientos (233). Esto nos lleva a pensar no sólo en esclarecer los procedimientos del metateatro, sino también en intentar identificar indicios de su posible recepción.

Para Catherine Larson, el metateatro no es una metodología per se, ni es tampoco una teoría, "aunque podríamos decir que la forma de entender el fenómeno sí es una herramienta interpretativa" (1015). Esto significa que, en cierta medida, si se trata de una forma de entender e interpretar un aspecto del funcionamiento del teatro, entonces se está considerando una forma de recepción que en buena medida depende de la percepción o la mirada del receptor y de su repertorio personal, pero -en la lectura hermenéutica que proponemos- también del repertorio del texto dramático. Así, surgen algunas preguntas: ¿Cómo es percibido esto por el lector?, ¿cuáles son los efectos que produce el metateatro?; si se producen ciertos efectos, $\dot{i}$ se distinguen consecuentemente estos dos modos de metateatralidad: el especulativo y el dramático?

Para intentar responder estas preguntas, adoptaremos una postura crítico-analítica, situándonos principalmente en el punto de vista de nuestra propia recepción con base en la concepción psicoanalítica o cognitiva del sujeto percibiente teórico, que mencionamos al inicio a propósito de Pavis. En la perspectiva de la estética de la recepción, esta postura se entiende como intrínseca al texto dramático, es decir, el horizonte de recepción se reconstruye no de forma empírica, sino a partir de los "blancos" y de los indicios que el propio texto otorga y de su repertorio. La siguiente propuesta metodológica es la que asumimos seguir en análisis posteriores para los fines que buscamos en este artículo.

Decíamos, líneas atrás, que el primer "nivel" que se abre ante el lector es el de la teatralidad, el de la "reconstrucción de la obra dramática" - diría Barrientos-. En este nivel, podemos considerar que el acto de lectura comienza a realizarse a partir de las expectativas tanto del dramaturgo como del lector: la realización virtual de un texto artístico escrito para su representación. El segundo nivel, el del metateatro, depende de que el receptor comience a advertir en su lectura la presencia de más de un nivel dramático en el texto.

Ahora bien, debemos preguntarnos cuáles son las coordenadas de las obras que proponemos analizar y de su recepción. A partir de estas reflexiones, esta investigación continuará de la siguiente manera: analizar la recepción del metateatro en el teatro áureo con base en una lectura que parta del repertorio del texto. Ésta se hará según la metáfora barroca del theatrum mundi, tanto desde el plano de la forma como desde el contenido. Así, sería posible realizar una reconstrucción que diera cuenta de algunos indicios sobre cómo pudo haber sido la recepción de lo metateatral. Los resultados de esta lectura podrían ser una posibilidad más para ver al metateatro como uno de los dispositivos más recurrentes en el teatro español áureo, en buena medida, como producto de su entorno social e ideológico. Esto apoya la idea de que pueda ser considerado como un mecanismo de producción de sentido en la espectacularidad; propuesta que, a su vez, permite ver al teatro áureo como 
generador de interesantes perspectivas para su estudio y montaje, así como considerarlo en relación con el teatro actual. Pues el metateatro es un mecanismo que, tanto en aquel momento como en la contemporaneidad, involucra al lector-espectador de manera activa, en una lectura o una puesta en escena que lo motiva y lo cuestiona sobre la posición que ocupa en ella y más allá de ella.

\section{El horizonte del teatro español barroco}

En general, el teatro barroco europeo se realizó sobre el influjo cultural de distintos tópicos (ser/parecer ser, el mundo al revés, la mujer vestida de hombre, engañar con la verdad, entre otros). Uno de los más presentes es el del theatrum mundi. Al respecto, cito el siguiente planteamiento de Erika Fischer-Lichte:

El teatro barroco aparece como un tema elegido para su estudio, ya que la concreción de la teatralidad, la actualización de las correlaciones entre el teatro y la cultura de su entorno, en ninguna otra época de la historia teatral occidental se pone tan evidentemente como condición para la posibilidad de teatro actualizado. Cuando se puede encontrar la metáfora dominante y característica del Barroco en todas partes del topos del theatrum mundi, del teatro vitae humanae. En él aparecen el «teatro» y el «mundo», o sea la «vida humana», como dos dimensiones relacionadas entre sí, que sólo pueden caracterizarse y comprenderse adecuadamente mediante la referencia a su relación recíproca (Semiótica del teatro 299).

Esta consideración plantea los puntos de contacto que pueden hallarse entre la visión del teatro barroco desde este tópico, así como su permanencia y vigencia en las teatralidades actuales: su presencia o uso permite establecer una relación directa de actualización entre el teatro y la realidad que le da espacio y tiempo. En el caso de España, Emilio Orozco (El teatro y la teatralidad del barroco) y José Antonio Maravall (La cultura del barroco) han hablado ampliamente sobre el teatro y la teatralidad del barroco como un modo de ser, que se constituía como parte de la realidad cotidiana de los españoles que habitaban principalmente las urbes en las que el teatro tuvo su mayor auge: Madrid, Sevilla, Zaragoza, Valencia.

Este modo de vivir y concebir la realidad podía reflejarse en el teatro, hasta cierto punto, desde en los detalles de su nivel más cotidiano (a través de la comedia de capa y espada, por ejemplo), hasta en la teatralización deliberada de la corte o del mundo en el auto sacramental por parte de los poetas, autores de comedias y comediantes. "Se produce un 
verdadero desbordamiento de lo teatral, no sólo de su sentido y expresividad, sino también de sus mismas formas" (Orozco 171).

Esta cosmovisión era también un "credo estético" para la poética del barroco, la cual pone de manifiesto el carácter ficticio de la realidad e interpreta al mundo mediante las parábolas de "la vida como sueño" y "el mundo como un teatro" (García Gutiérrez 863864). Tenía también un sustento teológico de raigambre medieval, que en la época barroca encontró en el teatro uno de sus mejores medios de expresión. Ello se entendía desde las dos grandes visiones filosóficas de Occidente: la platónica y la aristotélica. Así lo menciona Austin O'Connor:

En la filosofía idealista de Platón nada puede ser real, ya que todo es reflejo de alguna esencia eterna. La epistemología de Aristóteles modificó esta visión, y el papel de la razón, en su sistema, elevó la realidad a niveles de respetabilidad, ya que, mediante la razón, el hombre podría llegar a la verdad, la cual era eternamente distante dentro de la cosmología de Platón. ${ }^{5}$

Santo Tomás de Aquino retoma las ideas de Aristóteles y plantea los fundamentos de la cosmovisión cristiano-medieval del mundo: "St. Thomas Aquinas founding his system on Aristotle, asserted that reason could arrive at truth; but some truths are beyond the capacity of man's reason, and therefore God's revelation aids and points out divine truth directly" (Ibídem). La España del siglo XVII es el escenario de encuentro entre estas dos visiones cristiano-medievales: "In Spain this Neo-Platonism was grafted on an Aristotelian-Thomistic stem, which was a holdover from the Middle Ages" (279). Es un hecho que el teatro español reflejó esta perspectiva de una forma innovadora en relación con el antropocentrismo de los dramaturgos ingleses y franceses. Fue la Contrarreforma católica la que condicionó esta realidad plenamente barroca desde el theatrum mundi para los españoles del teatro áureo.

For the Spanish dramatists the world is indeed a stage — but a real stage- - [...] The man who "plays" a part is unauthentic, false and inevitably doomed to deceive himself about the nature of reality. The man who is true to his Christian faith is not an actor; he is a man being proved and tested by God (Ibidem).

5 In Plato's idealist philosophy nothing could be real since all is a mere reflection of some eternal essence. Aristotle's epistemology modified this view, and the role of reason in his system elevated reality to a levels of respectability since, by reason, man could arrive at truth -some eternally distant in Plato's cosmology (278). 
Además de la teatralidad ideológica con la que se vivía la vida en España, este sentir está en el teatro áureo -entre otras cosas- porque gracias al gran éxito que adquirió su representación fue un fenómeno que tuvo como "uno de los rasgos más destacables [...] la pluralidad de espacios exteriores, interiores y profesionales" (Diez Borque, "Teatro español” 139). El espacio donde se representa el teatro, dice también Diez Borque:

no es cuestión accesoria y sin importancia [...], pues afecta, naturalmente, a la puesta en escena, supone una pluralidad de "géneros canónicos", distintas órbitas de teatralidad y, obviamente, implica una variedad de "públicos", lo que es fundamental para entender hoy nuestro teatro clásico (Ibidem).

Esta reflexión es importante, por un lado, para distinguir la manera en que este teatro era entendido en su momento en relación con el nuestro (hablando, en general, del teatro occidental). Al respecto, dice Diez Borque: "El lugar privilegiado y fundamental de difusión del teatro es el teatro y no el espacio privado de la biblioteca, que implica, además, en el caso del teatro español del Siglo de Oro, una heterogeneidad de públicos" (Literatura 82). Y podemos completar esta idea con la siguiente de Felipe B. Pedraza: "Tengamos en cuenta que, aunque hoy haga las delicias de innumerables lectores, la comedia no fue creada para la lectura. Su vida estaba en la escena, en la voz y en el gesto del actor" (115). Por otro lado, este auge permite rastrear la presencia que tenía el teatro en el imaginario de la España barroca. Al respecto, dice también Pedraza:

[...] también llegó la pasión por el teatro a ciudades de menor población (Almagro, Alcalá, Écija...) e incluso a los pueblos. Existió una tupida red de teatros que permitía que las compañías ambulantes recorrieran toda España representando cada día. Hoy conocemos razonablemente bien muchos de esos espacios teatrales y la vida y el arte que en ellos se desarrollaban (109).

Así pues, podemos decir que la intensidad de la actividad teatral resultaba ser un factor fundamental para que los españoles de esta época sintieran al teatro como parte importante de sus vidas, según lo plantean Orozco y Maravall en sus clásicos estudios. Es así que, efectivamente, en el teatro español áureo uno de los tópicos recurrentes (ya en su temática, ya en los dispositivos dramáticos) fue el del theatrum mundi.

A este respecto, tenemos la recopilación de José Hesse de testimonios de distintas procedencias sobre el teatro áureo en Vida teatral en el Siglo de Oro, donde se cita a letrados, poetas dramáticos, comediantes, preceptistas, religiosos, notarios, testimonios anónimos, etcétera. Entre todos los que conforman el libro, podemos destacar un tes- 
timonio sobre los espacios que ocupaban los espectadores en el corral, la descripción sobre la división por estrato social y las tretas de la alta nobleza. Por ejemplo, los reyes se divertían no sólo con la representación, sino también con los apuros entre mujeres y mosqueteros, ${ }^{6}$ en ocasiones provocados por los nobles. Son éstos buen ejemplo de la teatralidad que va más allá de las tablas:

El 14 de septiembre los Reyes se entretienen en el Buen Retiro oyendo la comedia en el Coliseo, donde la Reina nuestra señora, mostrando gusto de oírlas silbar, se ha ido haciendo con todas, buenas y malas, esta misma diligencia. Asimismo, para que viese todo lo que pasa en los corrales en la cazuela de las mujeres, se ha representado bien a lo vivo mesándose y arañándose unas, dándose vaya otras y mofándose los mosqueteros. Han echado entre ellas ratones en cajas que, abiertas, saltaban; y ayudando este alboroto de silbatos, chiflos y castraderas se hacen espectáculo más de gusto que de decencia (Hesse 75).

Otros testimonios similares los proporciona Juan Zavaleta en El día de fiesta en Madrid y sucesos que en él pasan. ${ }^{7}$ Allí se describe graciosamente la vida cotidiana de los madrileños para "ir a la comedia" durante un día entero, desde la mañana hasta el suceso completo de la representación. La siguiente descripción pone en evidencia la antesala del espectáculo, desde la organización del acomodo de los espectadores, hasta la preparación de los comediantes detrás del tablado a partir del punto de vista del espectador que ronda estos espacios extradramáticos:

Come atropelladamente el día de fiesta el que piensa gastar en la comedia aquella tarde: el ansia de tener buen lugar le hace no calentar el lugar en la mesa. [...] Pasa adelante nuestro holgón y llega al que da los lugares en los bancos. Pídele uno y el hombre le dice que no hay, pero que le parece que a uno de los que tiene dados no vendrá su dueño, que aguarde a que salgan las guitarras, y que si entonces estuviere vacío se siente. Quedan deste acuerdo, y él por aguardar entretenido, se va al vestuario. Halla en él a las mujeres desnudándose de caseras para vestirse de comediantas (267).

6 Los llamados "mosqueteros" eran hombres que iban a la comedia que se representaba en corrales y coliseos con el objetivo de abuchear la representación y causar desmanes. Parece que realmente eran temidos, tanto por los poetas dramaturgos como por las compañías teatrales.

7 Según la noticia de Enrique Suárez Figaredo, este texto "se publicó en dos partes: El día de fiesta por la mañana... (Madrid, 1654) y El día de fiesta por la tarde... (Madrid, 1659), estampadas en la imprenta de María Quiñones" (146). 
Zavaleta describe también cómo las mujeres toman su lugar en la "cazuela", sitio del corral destinado a ellas para que no se mezclaran con los hombres, y evitar, así, incidentes vergonzosos: "[...] Entran y hállanla salpicada. No toman la delantera, porque ese es el lugar de las que van a ver y ser vistas" (270).

Igualmente, Zavaleta describe la suerte de los comediantes en relación con los ataques de los mosqueteros o la ausencia de público. Aquí aprovecha para dar más información de las entrañas de la actividad teatral: la preparación de los espectáculos por parte de las compañías, los ensayos y el empeño de los comediantes, no sólo por agradar a los espectadores, sino por tratar de ser atacados lo menos posible durante "la comedia", principalmente por los mosqueteros:

Veamos ahora en fee de qué [los mosqueteros] se atreven a hablarles mal los que allí se les atreven en fee del embozo de la bulla. Saben que todo aquel teatro tiene una cara, y con la máscara de la confusión los injurian [a los comediantes]. Ninguno de los que allí les dicen pesadumbres injustamente se las dijera en la calle sin mucho riesgo de que vengasen ellos o de que la justicia los vengase. Fuera de ser sinrazón y cobardía el tratarlos allí mal, es inhumano desagradecimiento, porque los comediantes son la gente que más desea agradar con ser su oficio entre cuantos trabajan en la república. Tanta es la prolijidad con que ensayan una comedia, que es tormento de muchos días ensayarla. El día que la estrenan diera cualquiera de ellos de muy buena gana la comida de un año por parecer bien aquel día. En saliendo al tablado, ¿qué cansancio, qué pérdida rehúsan por hacer con fineza lo que tienen a su cargo. [...] Con tan gran extremo procuran cumplir con las obligaciones de la representación por tener a todos contentos que, estando yo en el vestuario algunos días que había muy poca gente, les oía decirse unos a otros que aquellos son los días de representar con mucho cuidado, por no dar lugar a que la tristeza de la soledad les enflaquezca el aliento, y porque los que están allí no tienen la culpa de que no hayan venido más (268).

Este testimonio es muy interesante porque, a partir de la observación sobre las ventajas del anonimato del espectador, el autor invierte el punto de vista y ubica a los comediantes como espectadores de, metafóricamente, esa máscara colectiva que oculta la identidad individual y que por ello ataca sin empacho a los comediantes. Todo esto habrá influido en los dramaturgos para la generación de resortes dramáticos en el uso de técnicas metateatrales a través de situaciones en las que los espectadores se habrán visto reflejados. Si la estética del barroco español estaba influida por este topos, entonces era considerado seguramente en la composición dramática, y más aún, en la representación. Sobre esto, Diez Borque observa que "aparece la recepción como criterio básico en el afianzamiento y justificación 
de la comedia nueva. Por eso la comedia se construye, lo veremos, como un perfecto mecanismo de recepción, con un diseño calculadísimo" ("Lope de Vega" 41-42).

Por otra parte, el libro de Zavaleta ofrece también testimonios correspondientes a otro tipo de espectador, uno más letrado que los hombres y las mujeres de los que acabamos de hablar. Seguramente tomando en cuenta su propia experiencia en los espectáculos teatrales, este autor considera un tipo de recepción más versado en cultura literaria, crítica y reflexiva en relación con la construcción artística de "la comedia", el deleite estético y la necesidad de educar al espectador, más allá del puro divertimento o de recibir el mensaje de instrucción didáctica:

Ahora bien, quiero enseñar al que oye comedias a oírlas, para que no saque del teatro más culpas de las que llevó. Procure entender muy bien los principios del caso en que la comedia se funda, que con esto empezará desde luego a gustar de la comedia. Vaya mirando si saca con gracia las figuras el poeta, y luego si las maneja con hermosura, que esto hecho bien suele causar gran deleite. Repare en si los versos son bien fabricados, limpios y sentenciosos, que si son desta manera le harán gusto y doctrina, que muchos, por estar mal atentos pierden la doctrina y el gusto. Note si los lances son nuevos y verisímiles, que si lo son hallará en la novedad mucho agrado, y en la verisimilitud le hará grande placer a la mentira con todo el aire de la verdad. Y si en todas estas cosas no encontrare todo lo que busca, encontrará el deleite de acusarlas, que es gran deleite. [...] Esto en cuanto a lo que se puede notar en lo escrito de una comedia (269).

A continuación, Zavaleta alude a los elementos espectaculares de la comedia: el vestuario, gestualidad, decoro, que las acciones coincidan con las palabras, la encarnación de los personajes en general, los bailes:

[...] vamos ahora a lo que se ha de atender en lo representado. Observe nuestro oyente con grande atención la propiedad de los trajes, que hay representantes que en vestir los papeles son muy primorosos [...]. Repare si las acciones son las que piden las palabras, y le servirán de más palabras las acciones. Mire si los que representan ayudan con los ojos lo que dicen, que si lo hacen le llevarán los ojos. No ponga cuidado en los bailes, que será descuidarse mucho consigo mismo. Haga, fuera desto, entretenimiento de ver al vulgo aplaudir disparates y tendrá mucho en qué entretenerse. Gastando desta manera el tiempo que dura una comedia no habrá gastado mal aquel tiempo. Siendo esto así, me holgara yo mucho de que hiciera de aquellos ratos empleo apacible y provechoso (Ibídem). 
Podemos identificar aquí que, detrás de estas recomendaciones, necesariamente se plantea una posición objetiva y razonada de la recepción, lo cual habría implicado una distancia frente al fenómeno teatral, desde el punto de vista de los procesos de identificación en el momento de la representación. Se trata de reflexionar críticamente sobre los procedimientos de construcción para valorarlos. Pero también se trata de ver al espectador menos avisado, al "vulgo", como parte del gran espectáculo social que era la comedia.

Tener en cuenta al receptor como premisa implicaba que la comedia estaba, entonces, construida con una buena cantidad de guiños dirigidos a aquél -piensa Diez Borque-, o sea, con "técnicas para dirigir su atención" ("Lope de Vega" 42). Por su propia naturaleza, el metateatro como tema, como forma o técnica era un estimulante fundamental para la recepción: implicaba el cuestionamiento de la construcción de la realidad (ficticia o "real"), y por ello, el lugar que el espectador ocupaba en ella.

Carmen Hernández Valcárcel considera, por ejemplo, que "hay que convenir en el fuerte vitalismo barroco que pretende implicar al lector o al espectador en la problemática expresada sobre el escenario" ("Algunos aspectos del teatro" 96). Pero, la inmersión del receptor en el teatro áureo dependía también de convenciones genéricas. Al respecto, la misma autora menciona que "la práctica del teatro en el teatro se produce en todos los géneros, pero con diferente tratamiento, derivado de sus peculiares estéticas propias, del público o el medio al que se dirige, de los actores que representan la ficción, etc." (Ibídem).

\section{Conclusiones}

Así pues, si reflexionamos sobre los modos de producción y de recepción metateatral, según los propone García Barrientos, con base en el horizonte de expectativas del teatro barroco español, podemos decir que la producción metateatral tiene dos modos de ser: el dramático, cuyas técnicas son el metateatro, el metadrama y la metadiégesis; así como el especulativo, que corresponde a la tematización de éstos a la luz del tópico del theatrum mundi y que, en un momento dado, puede tomar forma en la estructura del drama.

Por su parte, la recepción metateatral puede reconstruirse con base en los tres niveles dramáticos del teatro dentro del teatro: el extradramático, que corresponde al plano escénico; el intradramático, que corresponde al plano ficticio, y el metadramático, que se refiere al drama dentro del drama, por el cual se movería entre el extradramático y el intradramático, según la técnica metateatral y el efecto que produjera.

Para la composición de su texto, el poeta dramático áureo habría considerado no solamente los aspectos intrínsecamente artísticos a la composición, sino también los relativos a la realización del montaje; esto es, el repertorio de la comedia para seguirlo o matizarlo con 
base en la fórmula lopesca de la Comedia Nueva, según el periodo de producción, y seguir o matizar también el modelo del subgénero elegido (comedia de capa y espada, comedia palaciega, comedia de santos, auto sacramental, tragedia histórica, comedia de comendadores, etcétera). Asimismo, habría considerado a la compañía teatral candidata para la venta y la puesta en escena de su comedia (habría pensado principalmente en los atributos de los comediantes en cuestión), y habría reflexionado en el espacio escénico para la representación (si sería abierto, cerrado, un corral, un salón de palacio, una casa, ambiente rural, ambiente urbano). Finalmente, también habría tomando en cuenta si la comedia era para alguna celebración especial, cortesana o religiosa, o simplemente una comedia de temporada teatral para corral o coliseo.

Todos estos factores de influencia en la composición dramática habrían sido determinantes para que el poeta imaginara cómo se daría la relación entre el espectador y los comediantes en los planos extradramático e intradramático durante la representación, y por tanto para que determinara que uso le convenía hacer de la metateatralidad: si como tema, parte estructurante de la trama o a través de técnicas en escena o situaciones específicas. Así, la comedia presentaba una estética teatral que implicaba fines didácticos, pero muchas veces también rasgos autorreferenciales sobre la práctica teatral, en ocasiones simplemente como recurso de divertimento.

Todo esto respondía, en definitiva, a distintas recepciones, como lo apunta Diez Borque y lo muestran los testimonios presentados. Habría espectadores que sólo iban a divertirse a "la comedia", quienes se implicaban en los vericuetos cotidianos de la representación antes, durante y después de ésta, en los espacios extradramáticos. Habría espectadores que, por su alto nivel socioeconómico y el lugar que ocupaban en los corrales o los coliseos, considerarían al movimiento de los espectadores de estratos sociales bajos y su interacción con los comediantes como parte del espectáculo (y tal vez como la parte más divertida de éste). Habría un tercer tipo de espectador quien -además de interesarse en todo lo anterior y con un sentido más reflexivo y crítico del arte teatral-, prestaría también atención a lo concerniente a la eficacia de la construcción artística de los versos y el espectáculo por parte del poeta dramático, incluyendo la interpretación de los papeles por parte de los comediantes.

Ante este complejo panorama de recepción, tanto el autor de comedias como los comediantes debían pensar en mecanismos que produjeran llamados de atención constantes a los diversos espectadores para lograr mantener su atención y, en la medida de lo posible, una atención más o menos benévola. Estos efectos podían producirse con prolijidad mediante el uso de técnicas y tópicos metateatrales que involucraran, de manera directa y activa, al público, aunque ello supusiera muchas veces arriesgarse a generar reacciones adversas en sectores de espectadores y a que la comedia terminara en situaciones incontrolables. 
Este horizonte de expectativas nos permite identificar, en los textos dramáticos del teatro español barroco, al metateatro como productor de unos efectos de sentido que se relacionaban directamente con la propia actividad teatral en su época y durante la representación. En ciertas ocasiones, la comedia podía estar imitando sucesos en los tres niveles recepcionales: el extradramático, el intradramático y el metadramático, oscilando entre uno y otro.

Así también, podríamos decir que la importancia del metateatro en las comedias habría estado en si se utilizaba sólo como recurso técnico, como tema, o incluso de forma temático-estructural. Ello habría dependido, decíamos, del subgénero en cuestión, pero también del estilo del poeta dramático y de la etapa de composición y representación de la obra, así como del espacio de representación. Como lectores del metateatro, deberemos tener en cuenta tal horizonte y las particularidades de la comedia en cuestión, para percibir y entender un fenómeno de teatralidad que en la actualidad se usa y puede seguir usándose. Se trata de uno de los resortes esenciales para captar la atención de aquel espectador que aún asiste a ver teatro clásico hispánico y que puede ser seducido por esta visión del theatrum mundi -la cual, desde la perspectiva de las nuevas teatralidades, es uno de los referentes de la realidad que tanto el arte escénico clásico como el contemporáneo, muchas veces evocan y representan.

Lo interesante para el seguimiento de esta investigación será pasar de la recepción del "sujeto psicoanalítico, percibiente y cognitivo" a la recepción del "sujeto sociológico, colectivo y empírico", para contrastar lo aquí expuesto e indagar cómo se producen los efectos de la metateatralidad en el espectador (desde dónde y cómo los percibe, qué le significan a partir de un corpus dramático). En particular, a partir de este corpus del teatro clásico hispánico, donde dichos efectos pudieran considerarse con mayor énfasis en el desarrollo del montaje y como una más de las estrategias para su actualización. Podremos corroborar, así, en qué porcentaje nuestra propuesta se refleja patentemente durante el acto de la representación escénica, para de ahí generar postulados metodológicos que, en un momento dado, puedan ser de utilidad para el análisis de los espectáculos teatrales.

\section{Fuentes consultadas}

Abel, Lionel. Metatheatre: A New View of Dramatic Form. New York: Hill and Wang, 1963. Bobes Naves, María del Carmen. Semiología de la obra dramática. 2a ed. Madrid: Arco Libros, 1997.

Diéguez, Ileana. "Escenarios y teatralidades liminales. Prácticas artísticas y socioestéticas”. Archivo Virtual de Artes Escénicas, ARTEA, Universidad de Castilla-La 
Mancha, 2009, artesescenicas.uclm.es/index.php?sec=texto, consultado el 15 de octubre de 2018.

Diez Borque, José María. Literatura (novela, poesía, teatro) en bibliotecas particulares del Siglo de Oro español: 1600-1650. Madrid: Iberoamericana-Vervuert, 2010.

Diez Borque, José María. “Teatro español del siglo xviı: pluralidad de espacios, pluralidad de recepciones". El teatro del Siglo de Oro ante los espacios de la crítica. Encuentros y revisiones. Editado por Enrique García Santo Tomás. Madrid: Vervuert, 2002, pp. 139-172.

Diez Borque, José María. "Lope de Vega y los gustos del vulgo". Teatro: revista de estudios teatrales, núm. 1, 1992, pp. 7-32.

Fischer-Lichte, Erika. Estética de lo performativo. Introducción de Óscar Cornago. Traducido por Diana González Martín y David Martínez Perucha. Madrid: Abada Editores, 2004.

Fischer-Lichte, Erika. Semiótica del teatro. Traducido por Elisa Briega Villarubia. Madrid: Arco Libros, 1999.

García Barrientos, José Luis. Cómo se comenta una obra de teatro. Ensayo de método. $2^{\mathrm{a}}$ ed. Madrid: Síntesis, 2007.

García Gutiérrez, Juan. "Dos aspectos de la cosmovisión barroca: la vida como sueño y el mundo como teatro". Revista de Estudios Extremeños, vol. 58, núm. 3, 2002, pp. 863-876.

Hernández Valcárcel, Carmen. "Algunos aspectos del teatro dentro del teatro en Lope de Vega”. Anales de Filología Hispánica, núm. 4, 1988-1989, pp. 75-96.

Hesse, José. Vida teatral en el Siglo de Oro. Madrid: Taurus, 1965.

Hornby, Richard. Drama, Metadrama and Perception. Lewisburg: Bucknell University Press, 1986.

Iser, Wolfgang. "El proceso de lectura”. Textos de teorías y críticas literarias (Del formalismo a los estudios poscoloniales), editado por Nara Araújo y Teresa Delgado. Ciudad de México: Universidad Autónoma Metropolitana-Iztapalapa/Universidad de la Habana, 2003, pp. 485-513.

Larson, Catherine. "El metateatro, la comedia y la crítica: hacia una nueva interpretación". Actas del X Congreso de la Asociación Internacional de Hispanistas, editado por Antonio Vilanova. Barcelona: Asociación Internacional de Hispanistas, 1992, pp. 1013-1020.

Leñero, Carmen. Del faro al foro: la imaginación novelesca frente a la imaginación teatral. Ciudad de México: Instituto de Investigaciones Filológicas-unam, 2016.

Leñero, Carmen. La escritura invisible. Teatralidad en textos filosóficos y literarios. Ciudad de México: Instituto de Investigaciones Filológicas-UnAM/CONACUlTA, 2010. 
Maestro, Jesús G. "Cervantes y Shakespeare: el nacimiento de la literatura metateatral". Bulletin of Spanish Studies. Essays in memory of E. C. Riley on the Quartercentenary of Don Quixote, editado por Jeremy Robbins y Edwin Williamson, vol. 81, núms. 4-5, 2004, pp. 599-611.

Maravall, José Antonio. La cultura del barroco. Madrid: Ariel, 1975.

O'Connor, Thomas Austin. "Is the Spanish Comedia a Metatheater?" Hispanic Review, vol. 43, núm 3, 1975, pp. 275-291.

Orozco, Emilio. El teatro y la teatralidad del barroco. Barcelona: Planeta, 1969.

Pavis, Patrice. Análisis de los espectáculos. Teatro, mimo, danza-teatro, cine. Traducido por Jaime Arrambide. Buenos Aires: Paidós, 2017.

Orozco, Emilio. Diccionario de la performance y del teatro contemporáneo. Traducido por Magaly Muguercia. Nuevo León: Universidad Autónoma de Nuevo León, 2014.

Orozco, Emilio. "Tesis para el análisis del texto dramático". Traducido por Isabel Martín. Gestos: teoría y práctica del teatro hispánico, núm. 33, 2002, pp. 9-34.

Pedraza, Felipe B. "Obra dramática". Lope de Vega. Vida y literatura. Salamanca: Olmedo Clásico/Gráficas Varona, 2008, pp. 109-185.

Von der Walde, Lilian. "La recepción: diversas proposiciones". Revista Casa del Tiempo, junio de 2004, pp. 2-12.

Zavaleta, Juan. "El día de fiesta en Madrid y sucesos que en él pasan". Lemir, revista de Literatura Española Medieval y del Renacimiento. Editado por Enrique Suárez Figaredo, núm. 20, 2016, pp. 145-344. 